\title{
(息)
}

Citation:

Burrai, E and Mostafanezhad, M and Hannam, K (2017) Moral assemblages of volunteer tourism development in Cusco, Peru. TOURISM GEOGRAPHIES, 19 (3). pp. 362-377. ISSN 1461-6688 DOI: https://doi.org/10.1080/14616688.2016.1236145

Link to Leeds Beckett Repository record:

https://eprints.leedsbeckett.ac.uk/id/eprint/4355/

Document Version:

Article (Accepted Version)

The aim of the Leeds Beckett Repository is to provide open access to our research, as required by funder policies and permitted by publishers and copyright law.

The Leeds Beckett repository holds a wide range of publications, each of which has been checked for copyright and the relevant embargo period has been applied by the Research Services team.

We operate on a standard take-down policy. If you are the author or publisher of an output and you would like it removed from the repository, please contact us and we will investigate on a case-by-case basis.

Each thesis in the repository has been cleared where necessary by the author for third party copyright. If you would like a thesis to be removed from the repository or believe there is an issue with copyright, please contact us on openaccess@leedsbeckett.ac.uk and we will investigate on a case-by-case basis. 


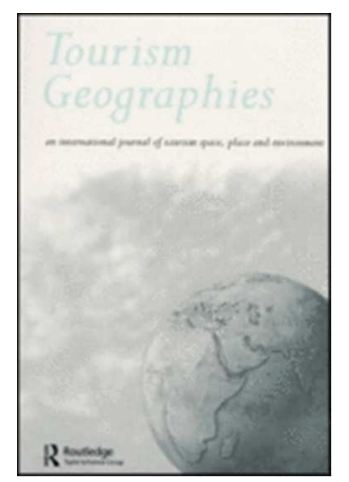

\section{Moral Assemblages of Volunteer Tourism Development in Cusco, Peru}

\begin{tabular}{|r|l|}
\hline Journal: & Tourism Geographies \\
\hline Manuscript ID & RTXG-2015-0248.R1 \\
\hline Manuscript Type: & Special Issue Article \\
\hline Keywords: & $\begin{array}{l}\text { Peru < SOUTH AMERICA, Assemblage Theory, Moral Landscapes, Volunteer } \\
\text { Tourism, Tourism Planning and Development, Cusco }\end{array}$ \\
\hline \multicolumn{2}{|l}{} \\
\hline
\end{tabular}

SCHOLARONE ${ }^{\mathrm{Im}}$

Manuscripts 


\title{
Moral Assemblages of Volunteer Tourism
}

\section{Development in Cusco, Peru}

\begin{abstract}
In this article we develop a conceptual approach from which to examine the moral landscape of volunteer tourism development in Cusco, Peru. Drawing from recent work on assemblage theory in geography and tourism studies, we explore how assemblage thinking can facilitate new understandings of volunteer tourism development. Using assemblage as an analytical framework allows us to understand volunteer tourism as a series of relational, processual, unequal and mobile practices. These practices, we argue, are constituted through a broader aggregation of human and non-human actors that co-construct moral landscapes of place. Thus, reconsidering volunteer tourism as assemblage allows for more inclusive and nuanced understandings of how geopolitical discourses as well as historical, political, economic and cultural conjunctures mediate volunteer tourism development, planning and policy. Finally, this paper calls for further research that integrates assemblage theory and tourism planning and development.
\end{abstract}

\section{Keywords}

Assemblage theory; moral landscapes; volunteer tourism; tourism planning and development; Cusco, Peru 


\section{Introduction}

In March 2016, it was widely reported that two tourists had been arrested by Peruvian police for posing naked at the World Heritage Site, Machu Picchu near Cusco, Peru. However, this was not an isolated occurrence, as in March 2014, the Peruvian government created new restrictions after a spate of tourists had taken their clothes off to take photos and run around the ruins. In June 2014, Minister of Culture, Diana Álvarez-Calderón, emphasized that nude tourism was "prohibited" and noted that "Machu Picchu is a religious sanctuary for the locals" (Peruthisweek.com, 2016). While this behaviour may be common at certain landscapes such as beaches, it highlights the moral nature of tourism. More broadly, such debates about moral and immoral behaviour in tourism has been discussed particularly in terms of contemporary volunteer tourism (Mostafanezhad and Hannam, 2014). In this paper we consider the development and planning of volunteer tourism in Cusco, Peru in terms of moral assemblages to offer a more subtle analysis of the wider political, economic and cultural context in which it materializes.

Going on a volunteer vacation in Cusco, Peru has fast become one of the most popular tourism experiences in the country, especially for 20-something Euro-American youth. While tourism scholars have paid significant attention to the impacts, outcomes, motivations and images of tourism in Peru (Steel, 2012; Scarles, 2012; Burrai et al., 2015), we know comparatively little about the role of volunteers in recent tourism development and planning in this region (Ladkin and Bertramini, 2002; Sinervo, 2015). More than 15 years ago Luke Desforges (2000) concluded that: it would seem that Peruvian tourism has gone through a major structural transition in which the tourism sector has undergone a considerable degree of 
institutional change. Further work on the neoliberal restructuring of tourism development will enable Peru's model of institutional change to be placed in an international context. Whether such a model of tourism development is beneficial to the lives and landscapes of those living and working in the tourism destinations of the 'pleasure periphery' remains to be seen.

It is from this starting point that we critically examine neoliberal tourism planning and development from the perspective of local volunteer host organisations in Cusco, Peru. Neoliberalism has broadly become regarded as the processes by which "marketbased regulation is expanded, the role of the state is reduced, and a complex array of public-private networks operate together" leading to the increased commodification of both human and non-human phenomena which are "subject to an expanding variety of market-based systems of management" (Duffy, 2008, p.329).

Specifically, we consider how neoliberal institutional transitions have both challenged and benefitted those at the front line of delivering volunteer tourism experiences in the wider international and moral context of the industry. In doing so we utilise the concept of assemblage as a way to think through the complex relations between morality, hosts, guests, planning practices and discourses. Assemblages are understood in this article as the heterogeneous combination of human and non-human actors and material components that mediate and are mediated by discourses of place and experience. Assemblage theory is useful in thinking through the spatiality of tourism as "processual, relational, mobile, and unequal" (McFarlane, 2011, p. 649). As DeLanda argues, the territorializing/deterritorializing, material/expressive and coding/decoding axes of assemblage "are variable and may occur in mixtures, that is, 
a given component may play a mixture of material and expressive roles by exercising different sets of capacities" (DeLanda, 2006, p. 12).

In tourism, the territorialization of place distinguishes "destinations" from "space" as it simultaneously contributes to new moral tourism landscapes. Volunteer tourism development is contingent, at least in part, on the moral landscapes in which it operates. These landscapes are co-constructed through myrid assemblage components which are embedded in the connections and orderings between the global North and the global South (Franklin, 2004, Oswin and Yeoh, 2010, Knollenberg et al., 2014). Assemblage theory arguably allows scholars to reconcile the "...modernist problem of the heterogeneous within the ephemeral, while preserving some concept of the structural so embedded in the enterprise of social science research. ... The time-space in which assemblage is imagined is inherently unstable and infused with movement and change" (Marcus and Saka, 2006: 102).

Drawing from recent work in this vein, we argue that the analytic of assemblage is a useful analytical framework from which to examine volunteer tourism planning and development in that it highlights processes of deterritorialisation and reterritorialization of the discursive and material co-construction of moral landscapes of volunteer tourism in Cusco, Peru. Additionally, this approach can faclititate a more nuanced theoretical lens through which to examine the complex and sometimes contradictory relationship between political discourses, moral geographies and tourism planning and development. To expand on these arguments, this article is organized as follows. First, we examine recent literature on volunteer tourism development and policy and assemblage theory to consider some of the theoretical 
implications of analyzing "volunteer tourism as assemblage". We then draw upon a case study of volunteer tourism in Cusco as an empirical example through which to consider what assemblage thinking might offer volunteer tourism planning and development. Finally, we consider the wider theoretical and policy implications of thinking through volunteer tourism as assemblage and call for further critically informed research into volunteer tourism development and planning.

\section{Volunteer Tourism as Moral Assemblage}

Beach resorts, theme parks and backpacker enclaves are all spaces of diverse moral sanctions - unwritten codes of behaviour that have social or material consequences which in turn, mediate tourist practice. As illustrated above, while it may be 'normal' practice for people to go unclothed on a designated nudist beach this behaviour may break moral codes when at a World Heritage Site such as Cusco. Indeed, "[t]he idea of a 'moral landscape' may be used to indicate how particular moral or normative understandings both influence and reflect the meanings that we ascribe both to natural landscapes and the built environment" (Popke, 2010, p. 436). Contemporary research meanwhile examines how morality is 'on the move,' highly fluid and mutating with changing mobilities. For instance, Allon et al., (Allon et al., 2008, p. 73) have analysed backpacker tourism in Sydney, Australia as a complex and mutating assemblage "of working, holiday and residential experiences that needs to be understood within a framework of increasing(ly) uneven, diverse and contested mobilities." In their example, the state, entrepreneurs and tourists frequently come into conflict over ostensibly moral issues. Yet, the changing spaces of these conflicts complicates issues for the state as it seeks to fix this situation figuratively and spatially in specific places. 
Diekmann and Hannam (2012) demonstrate the interplay of moral tourism concerns in Mumbai through the concept of performativity and illustrate how these moral concerns are territorialized in place - such as Mumbai - are also scaled out of place, deterritorialized, through the global media. Places are thus implicated within complex assemblages through which hosts, guests, buildings, objects and the media are contingently brought together to produce mobile performances (Hannam et al., 2006). This realization has led to a concern with the assemblage of "people, objects, capital and ideas in and through the overlapping scales of the local, the bodily, the national, and the global" (Oswin and Yeoh, 2010, p. 170). Moral landscapes of tourism are thus co-constructed through the assemblage of discursive and material components such as planning, advertisements, hotels and tours, in and through overlapping scales (Farias, 2010). Volunteer tourism, meanwhile, operates within a complex of moral assemblage components such as neoliberal ideologies (e.g. the privatization of development), the shareholders of multinational travel corporations, international volunteer tourists, awareness of, and interest in helping to ameliorate global poverty among people from the so-called global North, new communication technologies, local enterpreneurs and families struggling to earn a living and children trying to learn, among many others.

Assemblage, as "a multiplicity that exceeds its component parts" (McFarlane, 2009, p. 561), is a well situated analytic from which tourism scholars may work towards dissolving distinctions between micro/macro scalar tensions. This is in part, because the concept of assemblage points towards a focus on relations of exteriority where component parts cannot be reduced to their function within the whole and can simultaneously be part of multiplicities (Deleuze and Guattari, 1980; Collier and Ong, 
2005). Li illustrates how the concept of assemblage "emphasizes both temporality and spatiality: elements are drawn together at a particular conjuncture only to disperse or realign" (Li, 2007, p. 265). As Parker (2009, p. 111) argues, the point is to "deessentialize the assumed interplay between 'global' and 'local,' and focus instead on the encounters, connections, exclusions and erasures - both contingent and structured - that underpin the production of political agency at given moments in space and time."

Contemporary tourism planning and development operates at interconnected and shifting spatial scales (Hultman and Hall, 2011; Dredge and Jamal, 2013). Dredge and Jamal (2013, p.561) usefully point out that frequently, "no single agency has overall responsibility for tourism destination planning and management, a situation that exacerbates attempts to develop and implement a coordinated approach to sustainable tourism management." However tourism planning is also normalized through of moral codes within tourism geographies as is evident in an examination of volunteer tourism development (Butcher and Smith, 2010, 2015; Mostanfanezhad and Hannam, 2014).

The analytic of assemblage is conducive to the analysis of tourism planning and development as an attempt to understand the moral ordering of the cultural, political, economic, social and environmental practices among human and non-human actors and material objects. Foucault (1990) famously examined morality as a mode of ordering of socially constructed and embodied codes of the conduct of conduct. The internalization of these codes play a critical role in biopower that governs social (and biological) practices. Recently, volunteer tourism has been conceptualised as a 
technology of government, "the purpose of which is to align individual conduct with neoliberal capital's double injunction of market rationality and social responsibility" (Vrasti and Montsion, 2014, p. 336). Thus, the notion of assemblage is useful in trying to make sense of these modes of ordering in volunteer tourism planning and development in order to reveal the political interconnections of various components ranging from images, tourism operators, local and national governments, historical experiences, local community member presentations, among others. A focus on assemblage also "makes it possible to show how neoliberal projects preserve and assimilate 'authentic' social configurations (e.g., the community) into hegemonic projects of [capital] accumulation.” (Parker, 2009, p. 111). The conceptualization of tourism as assemblage allows for a more subtle understanding of the connections of tourism planning with other components where diverse understandings of the environment may be ordered into various moral landscapes (Waitt and Cook, 2007, Whatmore, 2002).

The proliferation of responsible tourism discourses have been identified as part of the broader neoliberalization of development and humanitarianism in tourism (Knollenberg et al., 2014). Building on Urry’s “tourist gaze,” Mostfanezhad integrates assemblage theory with emerging work on the geopolitics of emotion to develop what she calls the "humanitarian gaze" in volunteer tourism. In the context of volunteer tourism, she notes how "assemblage theory helps us tease out the diverse elements of the humanitarian gaze that is co-constituted in part, by volunteers, host community members, NGOs, state organizations, universities, supranational organizations, media, celebrities and corporate sponsors, among others" (2014, p. 12). Thus, in the context of volunteer tourism planning, moral assemblages point to the ways in which morality 
is always incomplete and a continual process open to rearticulation through new discourses of humanitarianism, which are mediated by transnational networks of power. In this way, she aregues that "We can think of the humanitarian gaze as a composite of disparate elements drawn together at various moments of intersection such as that between humanitarianism, popular culture and tourism” (ibid, p. 15).

In a similar vein, Butcher (2003), for example, describes a widespread moralization of tourism within the context of an expanding neoliberal rationality of care. This discourse of responsibility is intensified in the broadened focus on neoliberal assemblage components such as volunteer and ecotourists, NGO practitioners, neoliberal policies of privatized development and multinational corporate responsibility programmes. Thus, he develops a critical perspective on the discourse of "saving the world" through alternative (as opposed to mass) tourism experiences. In a similar vein, volunteer tourism is often uncritically applauded for the "care" shown by participants, despite the sometime inappropriate, unsustainable, or indeed harmful consequences that it engenders (Sin, 2010, Mostafanezhad, 2013, 2014). Nevertheless, Butcher and Smith (2010, p. 34) argue that:

Cynicism at the act of volunteering is certainly misplaced. The act of volunteer tourism may involve only simple, commendable charity. However where volunteer tourism is talked up as sustainable development and the marketing of the gap-year companies merges into development thinking, this is symptomatic of a degradation of the discourse of development. The politics of volunteer tourism represents a retreat from a social understanding of global inequalities and the poverty lived by so many in the developing word. 
Hence, the mapping of moral tourism assemblages may help us to develop a critique of the neoliberal policies and ideologies that mediate volunteer tourism planning and development. Moreover, this body of work is illustrative of how "neoliberalism can be usefully understood as an assemblage which comes together in much more disjunctive ways than is often recognised" (Larner, 2009, p. 1576). In what follows we outline the methodology on which this paper is based and apply the aforementioned theoretical framework to our analysis of an empirical case study of volunteer tourism planning and development in Cusco, Peru.

\section{Methodology}

The empirical research for this article is based on a six months of ethnographic research conducted in Cusco in 2010. Thirty qualitative, semi-structured, in-depth interviews were conducted with volunteer tourism stakeholders and host family members who reside in Cusco to understand how they engage with and adapt to volunteer tourism development and planning. The participants were identified using a combination of purposive and snowball sampling techniques. These two nonprobability sampling strategies were used to select informants who had direct links with the development of volunteer tourism. The resultant participant samples consisted of six project directors, 16 members of staff from aid projects, four volunteer recipients and four volunteer hosting families. The range of informants enabled an understanding of the complexities of volunteer tourism planning and development from the perspective of those primarly involved in the planning and development of volunteer tourism. One of the authors volunteered in two social projects, a shelter house and an after-school project, which were both identified 
during a pilot trip undertaken seven months prior to the data collection. Participant observation allowed the researcher to develop rapport with the respondents.

\begin{abstract}
All the interviews were conducted and transcribed in Spanish, with the quoted passages subsequently translated into English. The data collected were deductively analysed following key theoretical patterns identified in the literature on volunteer tourism. Subsequently, the emergent findings and themes were organised in analytic memos, which allowed reflection on the various connections among responses and to identify emergent concepts (Saldaña, 2009). Saldaña refers to analytic memos as a tool "comparable to researcher journal entries or blogs - a place to 'dump your brain' about the participants, phenomenon, or process under investigation by thinking and thus writing and thus thinking even more about them" (2009: 41). To protect the privacy of the research participants, all names of people and places are pseudonyms. The data from the interviews and field notes collected during the participant observation were then subsequently triangulated with relevant planning and policy documents from international agencies, the Peruvian government and local organisations, allowing a ‘bottom up' analytical approach.
\end{abstract}

\title{
Volunteer Tourism Planning and Development in Cusco, Peru
}

The City of Cusco, situated in the highlands of South East Peru and the gateway to Machu Picchu, is a UNESCO World Heritage Site famed for its Inca and colonial heritage (UNESCO, 2015). Tourism constitutes the primary industry in Cusco, with aproximately 2.8 million people visiting in 2013 , constituting 88 percent of all international visitors to Peru (World Bank, 2013). However, the World Bank 
recognises that despite the growth in tourism arrivals, there continues to be a relative lack of high quality tourism services in Cusco (World Bank, 2013, p. 3). The tourism industry including the numerous hotels, restaurants, bars and nightclubs in the city centre which are primarily owned and managed by outsiders, producing a high level of capital out-flow or leakage estimated to be over 90 percent of gross tourism revenues (Mitchell and Eagles, 2001; Steel, 2008; Larson and Poudyal, 2012) to other cities and countries. Consequently, as Van den Berghe and Ochoa (2000, p. 23) have observed, "tourism in Cusco has made virtually no contribution to the regional development" (2000: 23). Simultaneously, tourism has arguably exacerbated the unequal distribution, among residents, of the resources and benefits derived from tourism (Pacheco, 2007).

The popularity of Cusco among tourists has strong links with its historic past. As noted above, Cusco is well known for its $17^{\text {th }}$ century Sacred Valley of the Incas, its Inca trail and its iconic Machu Picchu (see figure 1 below). Tourist demand to rediscover Cusco's ancient history and traditions have driven its residents to commodify their culture for touristic consumption (Van den Berghe and Flores Ochoa, 2000; Desforges, 2000). It is common, for example, to see women wearing 'typical' colourful clothes and holding lambs or baby llamas asking tourists to take a picture in exchange for money. Indeed, Ypeij (2012, p.17) has noted that both indigenous people and mestizos display their ethnic identities in their tourism work and this has "become an integral part of these people's lives, social relations, and identities whether tourists are present or not." In line with the commodification of its folkloristic past in tourism, Cusco has also rediscovered the use of Quechua, the ancient native South American language spoken mainly by the indigenous people of 
the Andean regions. Although, after the Spanish invasion Quechua was predominately used by people of lower social classes, nowadays its use has spread throughout the city mostly for commercial purposes to convey a sense of authenticity to tourists (Pacheco, 2007).

[Insert Figure 1 here: Machu Picchu]

The Cusco Regional Government (CRG) recently developed the 2021 Cusco Strategic Development Plan (Plan Estrategico de Desarrollo Regional Concertado, Cusco a 2021) with support from the World Bank. This plan argues that it "specifically proposes investments in infrastructure that would accommodate the ongoing growth of the tourism sector with adequate consideration for environmental concerns and disaster risk mitigation” (World Bank, 2013, p. 3). The World Bank (2013, p. 6) has recently approved and begun to implement a US\$ 52 Million Cusco Regional Development Project which argues that it supports: the Bank's broader mission to end extreme poverty and promote shared prosperity, particularly through activities providing technical assistance to local small and micro enterprises providing tourism-related goods and services, targeted in the rural areas of the Sacred Valley where poverty and inequality are highest.

As with most World Bank projects, this project was predicated on a neoliberal model of developing small tourism businesses, the aim of which was to end poverty and promote shared prosperity. 
The project's environmental considerations include the expansion of the tourism carrying capacity of the region "by improving the delivery of solid waste services." The project also includes a "Social Inclusion Plan" which seeks to formalize waste pickers by providing employment opportunities for them related to recycling activities. The project further seeks to provide improvements in infrastructure to better withstand floods and landslides in order to increase resilience and protect vulnerable populations and tourists in the region. The project makes some bold and somewhat simplistic claims about the benefits of expanding tourism in the region through "expanding infrastructure and improving competitiveness to enhance tourism services and better integrate local value chains to maximize direct and indirect benefits" (World Bank, 2013, p. 13). There is an expectation on the part of the Peruvian Government that upgrading tourism attractions and services will lead directly to an increase in the number of tourists who visit, their length of stay, and their spending and that "[a]s a result, tourists' satisfaction and local residents' wellbeing would increase" (World Bank, 2013, p. 13).

It is in this context that a more complicated translocal assemblage of Cusco starts to emerge, involving the World Bank, local planning regimes, development workers and volunteer tourists as well as the iconic image of Cusco itself. The vibrant tourist scene clashes with the poverty stricken images of the city constructed for volunteer tourism (Keese, 2011). The vast number of aid organisations operating in the urban centre and surrounding districts address mainly social problems such as alcoholism, domestic violence and education (Burrai et al., 2015). As a gateway to Machu Picchu, numerous volunteer tourism opportunities have proliferated in Cusco to address the widespread demand for volunteers primarily for social and educational projects and 
since the millenium, volunteer tourism in Cusco has grown exponentially. By 2010 volunteer tourism activities had become a mainstay of the Cusco tourism experience. The expansion results from both an increase in demand (particularly from Western tourists) and, according to the residents, the government's negligence in social and assistance matters. Nonetheless, there are some inconsistencies in the relationship between the need for aid and volunteer tourism projects. In Peru, between 2003 and 2007 , the total number of aid projects increased from 51 to 192, placing it in third rank (after India and Costa Rica) in the "top ten countries for volunteer tourism expansion" (Tomazos and Butler, 2009, p. 201).

The vast majority of volunteering projects in Cusco are of a social nature, varying among orphanages, kindergartens, childcare after-school projects, centres for disabled children and/or shelter houses, hospitals and rehabilitation centres. Usually social projects follow the same seasonality as that of all other forms of tourism, with May to October being the most popular months. On average, projects receive between five and 10 volunteers at a time during these months, apart from exceptional cases such as organised groups of volunteers who travel together on school trips. Spanish language schools, tour operators and various types of international organisations and companies all sell volunteer tourism experiences. The average cost of a volunteer tourism experience in Cusco is around US\$600 for two weeks, however this price can vary considerably depending on the number of weeks and the services included in the package (e.g. salsa classes, cooking classes, tours in and around the city) (Burrai et al., 2015). 
The findings from the empirical research demonstrate discursive and material assemblages of global and local narratives regarding volunteer tourism development. Throughout these narratives, the power of Western colonial imaginaries of need, care and help are prominent. Assembled, in part, through neoliberal roll-backs of the state that reduced funding for the social programs targeted by volunteer aid organizations in Cusco, the image of the international volunteer tourist as a positive force for wider tourism planning and development was constructed (see figure 2 below).

[Insert Figure 2 here. International Volunteer Tourism Particpation in Cusco, Peru.]

Participating in this discourse of Cusco as in demand of international volunteer tourists, many respondents commented on the need for, and reliance on, external foreign help. For example, Dalmiro, a volunteer project director explained: “...without any doubt, at the moment, I see the need for stronger help; more support for the project from foreigners rather than from the local institutions of my place." As local institutions are rolled back as a result of neoliberal World Bank projects more emphasis is placed on privatized and non-governmental social development programs. Thus, the relationships between local needs and help from Western volunteers are associated with the deterritorialised nature of both volunteer tourism marketing (at a macro level) and the territorialised volunteering actions (at a micro level), as fostered by a range of international foreign entities including both NGO's and multinational tourism companies in the context of Peru's development strategies.

The Peruvian development strategy has evolved hand in hand with the neoliberalisation of the tourism sector under the government of Fujimori, who 
governed between 1990 and 2000, when "the boundaries between the state and the private sector were redrawn [... such that] Peru has been able to take advantage of new demands and retail mechanisms within First World tourist source markets" (Deforges, 2000: 188). The commercialisation of Peru's developmental strategies could be considered to have various moral considerations: positive on the one hand, as it is deemed to have improved the local economy and the financial situation of some, but negative on the other hand, as it is seen to have reinforced the control exerted by foreigners and/or local elites and widened inequalities.

Western models of knowledge and professionalism were considered, by respondents, to be advanced in comparison to Peru, which according to Daniel, a project director, “still has Third World problems." Sending organisations often initiate this by simplifying the problems at a destination level in an attempt to reduce the cultural gap between volunteers and locals through the production of an assemblage of representations and practices. This was evident, for example, in the volunteer information sheets that were distributed by the Spanish schools in Cusco. These sheets are the main point of contact for volunteers. They describe the social problems in Cusco, note the tasks that potential volunteers can expect to undertake and make explicit that they are "highly dependent" upon volunteers. For example, in relation to a women's shelter designed to give teenage mothers and their children (who had been subjected to physical and sexual abuse) a new home, volunteers were advised that: It is important to know that the level of knowledge of all the girls is really basic as the majority of them have hardly attended any school ever.. ... It is important for you to be proactive and to work independently in this project. The higher your level of Spanish is, the better your volunteer experience will 
be, especially if you are working as a professional. Also, it is highly appreciated if you leave a general donation such as diapers for the babies or material for creative activities at the project, in accordance with the director. [Information Sheet for Volunteers, Cusco, 2010].

In these information sheets, the narrative of dependency on international aid and volunteers is emphasised but also the ability to work proactively and independently. However, Miguel, a member of staff, explained that he was critical of this independence as many volunteers felt that they could just do whatever they liked: companies sell the volunteer experience in a way that volunteers can do whatever they like. So it depends on them. I see it as time that they are dedicating to learn and know more and, for this reason, they should adapt to the system and respect it.

Ultimately, the sending organisations are in a position of moral control over both the volunteers and the receiving organisations, as they filter and represent images and roles in accordance with their own commercial agendas.

Respondents referred negatively to both the government's negligence in dealing with the local socio-economic instability and the unregulated aspects of volunteer tourism programmes that had been introduced. As is typical of neoliberal approaches to tourism planning (Duffy and Moore, 2010), responses from those involved in the production of volunteer tourism highlighted the government's lack of ability in controlling, or using its authority to limit, external interventions in the country. This aspect was particularly noticeable in the growing number of local unplanned volunteer tourism programmes which caused frustration for some local stakeholders. Manuel, a member of staff on an aid project, commented that business has come first 
rather than providing development due to external agencies that commodify volunteer experiences:

volunteering has become a business because there are institutions that charge money to be a volunteer...especially Spanish language schools and travel agencies sell packages to 'meet the poor'. I don't like the fact that Spanish schools and agencies sell these experiences as part of a show!

Daniel, a project director, also expresseed his resentment towards the commodification of volunteering: "I think it is negative that so many agencies and Spanish schools charge foreigners $\$ 120$ dollars just because they think that gringos have money".

The lack of common values and aspirations as well as the enhancement of individualism and self-interest are key aspects of neoliberal subjectivities (Harvey, 2005). These subjectivities are replicated through volunteer tourism due to the activation of assemblages of responsibility. They are, therefore, expected to be responsible and committed to the work in the projects as Daniel, resentfully specified to one, unprepared volunteer:

Today you [volunteer] came [to the project] and you are not going to do as good as other volunteers who know in which class they have to be and who prepared their classes in advance. You came here without knowing anything about your class and without knowing about this project. I can't allow this! Because for me this is a lack of respect, firstly because this project is my life, it justifies me being here, in this world [...]. I tried to provide the volunteers with every possible document to use to be prepared for Mondays... 
Here Daniel articulates a key problem of the neoliberal conundrum, namely his values in contrast to the visiting volunteer who shows a lack of respect for the morality of the place in which s/he find herself. As Raymond and Hall (2008) have suggested volunteer tourism frequently leads to cross-cultural misunderstandings and the reinforcement of cultural stereotypes.

Examining volunteer tourism as assemblage in Cusco highlights the problem of moral agency which leaves those involved in the planning and development of volunteer tourism almost wholly dependent on volunteers that they deem inadequate to their needs. This sentiment also emerged with Diana, another project director, who, despite her negative feelings towards volunteers, had to accept them. She explained: "We [the project] live on charity. We don't have to talk to them [the volunteers] and I have to prepare psychologically [...] because there are people who I cannot be bothered to deal with..." In addition, Maya, a teacher in a public school, argued that:

The government doesn't know that we work with volunteers. Only the coordinator knows. The money that comes from the volunteers has to be invested in the school to buy something. The government does not give us $a$ sol and we have to find ways to manage the situation and ask for help...

Volunteer tourism in Cusco can thus be seen as part of a broader neoliberal assemblage of global discourses of care connected with local material need.

In Cusco, local stakeholders have also had an interest in keeping the volunteer tourism business informal mainly for financial reasons (to avoid taxation) and also to help eliminate the bureaucracy that would otherwise need to be dealt with. While the informality exposes some of them to economic and emotional vulnerability, others are 
able to take advantage of informal market opportunities as a form of resistance maintstream neoliberal capitalism. For example, Felicia commented that:

Families are really keen in getting involved to host volunteers because this is a way for them to earn money...there's a high unemployment rate in Peru and everyone has to make a way of living. I don't work for anyone, I depend on my work...and, like me, there are other people who have to find a way to survive. So I give volunteers to other families...

Felicia emphasised that her devolvement of work to other families was informal so that there were no contracts or other bureaucratic measures in place. She also noted that, in its totality, her volunteering business comprised of a Spanish language school, a volunteering project and numerous hosting families, some of which are run by her relatives. The range of volunteering experiences that Felicia is involved in is also indicative of the ways in which various assemblages of development discourse intersect in volunteer tourism. However, Felicia also expressed a number of moral concerns:

I am interested that foreigners know the city and that they know the other places around Cusco...but, when I see that they use Cusco and its people, that's what I don't like. Look, the volunteering theme is very broad but let me tell you something, there are many foreign companies, many foreigners that come here and make lots of money with the excuse that they are helping the poor and they also show a much poorer image of Cusco. These foreigners live off this poverty...

Felicia's comments illustrate how the moral landscape of Cusco is contested. Furthermore, she illustrates how the foreign companies and volunteers as not just making money out of 'helping the poor' but also in perpetuating an image of Cusco 
primarily as a place of poverty as has been noted elsewhere in South America (FreireMedeiros, 2013).

\section{Discussion}

Volunteer tourism development in Cusco is mediated by assemblages of images, experiences and discourses that re-present Cusco as an appropriate site of volunteer tourism. These contemporary assemblages of volunteering and tourism characterises the image of Cusco in the volunteer tourism market. The existence of social problems which are neglected by the Peruvian government justifies the proliferation of volunteer tourism opportunities in the city. Aid and local needs are romanticised for tourist consumption through the emphasis placed on the leisure and authentic elements of the experience. Overseas assistance, development and leisure are, therefore, assembled and delivered through powerful neoliberal discourses emanating in part from the Wolrd Bank which reinforce stereotypes and dependency on primarily Western volunteer tourists. Therefore, in the creation of a Cusco for volunteer tourism consumption, images of 'poor' local people are often associated with the adventure component of the volunteer tourism experience (e.g. tours around Cusco, salsa classes, etc.) but also simulataneously to the 'authenticity' of experiencing local life and poverty.

The availability of volunteer tourism opportunities and the simplified representations of need and aid have contributed to the uncritical mass consumption of volunteer tourism experiences in Cusco. Additionally, volunteering practices are crafted within a popular tourist environment making it difficult for volunteer tourists to balance their responsibilities as volunteers and their leisure time as tourists. The commercialisation 
of humanitarian actions was recognised by some informants as being positive for financial reasons, however, this has also exposed others to difficulties particularly in relation to tourism development which proceeds on an informal basis.

Additionally, the complexities related to the planning and managment of volunteer tourism in Cusco relates to the lack of policies to regulate the industry both at a macro and a micro level. This scenario clashes with the broader picture of international aid and the variety of private, public and charitable bodies involved in addressing social issues in Peru. A variety of governmental programmes promote the improvement of Peruvian' quality of life who live in high risk situations and in conditions of extreme poverty (e.g. PRONAA and PANFAR which are programmes to facilitate nutrition among poor people, FONCONDES which helps local development and MIMDES which supports women and Peruvians who live in disadvantage conditions) ${ }^{\mathrm{i}}$. Yet, these programmes are not linked with volunteer tourism organizations. There is also a lack of governmental interventions in regulating the volunteer tourism industry and controlling foreign aid activities. Many of the organisations involved in aid programmes are not formally registered with state-controlled (or other types of) schemes. Instead, they informally link to the market of transnational aid through commercial means of distribution channels which in Cusco include, predominantly, Spanish language schools.

The findings indicate that attempts at self-regulating volunteer tourism are informally made by local stakeholders. As Sinervo (2015, p. 169) has observed "the landscape of development and tourism in Cusco entails coinciding commodification, social justice, and travel agendas" which is negotiated by a variety of actors who often pursue very 
narrow individual interests. Personal interests towards commercial and/or philanthropic aspirations depend on the agenda of the actors involved. Whereas some residents prioritise the economic benefits that this form of tourism can bring to their personal lives, others contest the negative implications that commercialised imaginaries of Cusco and volunteering practices can have at a local and international level. On the one hand, the de-regulated nature of volunteer tourism allows some residents to exploit the informal market opportunities. On the other hand, some others are exposed to vulnerable market mechanisms which weaken their already fragile material situations. Additionally, representations of a 'poor' Cusco to attract volunteer tourists further encourage dependency through the association of progress in Western imaginaries of development.

In this way, Cusco itself is constructed through discursive representational assemblages of need and fun, which are appropriated in numerous ways by local stakeholders in the volunteer tourism industry. In some cases, the respondents highlighted the significant material and financial outcomes that derive from hosting volunteers in projects. The perceived dearth of governmental intervention to support local projects encourages directors to rely on the help of volunteer tourists. Yet, the paucity of internal policies which volunteers should follow, causes frustration for some residents who would like to host responsible volunteers in the projects. Mismanagement of volunteering practices in Cusco reflects not only the general lack of guidelines and policies, but it also reflects the ways in which the moral landscape of volunteer tourism in Cusco is composed of multiple and often contradictory assemblage components. 


\section{Conclusions}

This article integrates recent research on assemblage theory and moral landscapes with volunteer tourism development and planning in the context of Cusco, Peru. While scholars have drawn attention to the role of various intermediaries in the development of volunteer tourism in Cusco (e.g. Sinervo 2015), this article has developed an assemblage approach to understanding the complexities of volunteer tourism development in Cusco. This framework facilitated opportunities for examining the local co-production of meanings in order to articulate the complex, relational and contested space of volunteer tourism (Dredge, Hales and Jamal, 2013). Assemblage theory, we argue, offers new opportunities for thinking through how the ways assemblage components of volunteer tourism — ranging from media representions, intercultural encounters to affective engagements—can provide valuable insights for tourism planning and development practitioners. A reconsideration of volunteer tourism as a moral assemblage allows for a more inclusive and nuanced understanding of everyday geopolitical encounters in volunteer tourism. Additionally, by interrogating the complex networks from an assemblage theory framework, we can shed analytical light on the historical, political, economic and cultural conjunctures that mediate volunteer tourism. Finally, we call for further research that integrates assemblage theory and volunteer tourism development and policy.

\section{References}

Allon, F., Anderson, K. and Bushell, R. 2008. Mutant Mobilities: Backpacker Tourism in 'Global'sydney. Mobilities, 3, 73-94. 
Burrai, E., Font, X. and Cochrane, J. 2015. Destination Stakeholders' Perceptions of Volunteer Tourism: An Equity Theory Approach. International Journal of Tourism Research, 17, 451-459.

Butcher, J. 2003. The Moralisation of Tourism. London: Routledge.

Butcher, J. and Smith, P. 2010. 'Making a Difference': Volunteer Tourism and Development. Tourism Recreation Research, 35(1), 27-36.

Butcher, J. and Smith, P. 2015. Volunteer Tourism: The lifestyle politics of international development. London: Routledge.

Collier, S. and Ong, A. 2005. Global Assemblages: Technology, politics, and ethics as anthropological problems. Oxford: Blackwell.

Barnett, C., Cloke, P., Clarke, N. and Malpass, A. 2005. Consuming Ethics: Articulating the Subjects and Spaces of Ethical Consumption. Antipode, 2345.

Delanda, M. 2006. A New Philosophy of Society: Assemblage Theory and Social Complexity, London: Continuum.

Deleuze, G. and Guattari, F. 1980. A Thousand Plateaus, London: Continuum.

Diekmann, A. and Hannam, K. 2012. Touristic Mobilities in India's Slum Spaces. Annals of Tourism Research, 39(3), 1315-1336.

Desforges, L. 2000. State tourism institutions and neoliberal development: A case study of Peru, Tourism Geographies, 2(2), 177-192.

Dredge, D. and Jamal, T. 2013. Mobilities on the Gold Coast, Australia: implications for destination governance and sustainable tourism, Journal of Sustainable Tourism, 21(4), 557-579. 
Dredge, D., Hales, R. and Jamal, T. (2013) Community Case Studies in Tourism: Researcher Operacy, reflexivity and making research matter, Tourism Analysis, 18(1), 29-43.

Duffy, R. 2008. Neoliberalising Nature: Global Networks and Ecotourism Development in Madagasgar, Journal of Sustainable Tourism, 16(3), 327-344.

Duffy, R. and Moore, L. 2010. Neoliberalising Nature? Elephant-Back Tourism in Thailand and Botswana. Antipode, 42(3), 742-766.

Foucault, M. 1990. The History of Sexuality: The use of pleasure, London: Random House.

Franklin, A. 2004. Tourism as an Ordering: Towards a New Ontology of Tourism. Tourist Studies, 4, 277-301.

Freire-Medeiros, B. 2013. Touring Poverty. London: Routledge.

Hannam, K., Sheller, M. and Urry, J. 2006. Editorial: Mobilities, Immobilities and Moorings. Mobilities, 1(1), 1-22.

Hultman, J. and Hall, C. M. 2011. Tourism Place-Making: Governance of Locality in Sweden. Annals of Tourism Research, 39(2), 547-570.

Keese, J. 2011. The Geography of Volunteer Tourism: Place Matters, Tourism Geographies, 13(2), 257-279.

Knollenberg, W., McGehee, N. G., Boley, B. B. and Clemmons, D. 2014. Motivationbased transformative learning and potential volunteer tourists: facilitating more sustainable outcomes. Journal of Sustainable Tourism, 22(6), 922-941.

Ladkin, A. and Bertramini, A. M. 2002. Collaborative Tourism Planning: A Case Study of Cusco, Peru, Current Issues in Tourism, 5(2), 71-93.

Larner, W. 2009. Neoliberalism, Mike Moore, and the WTO. Environment and Planning A, 41, 1576-1593. 
Larson, L. R. and Poudyal, N. C. 2012. Developing Sustainable Tourism through Adaptive Resource Management: a Case Study of Machu Picchu, Peru. Journal of Sustainable Tourism, 20(7), 917-938.

Li, T. M. 2007. Practices of assemblage and community forest management, Economy and Society, 36(2), 263-293

Marcus, G. E. and Saka, E. 2006. Assemblage. Theory, Culture and Society, 23, 101106.

McFarlane, C. 2011. The City as Assemblage: Dwelling and Urban Space. Environment and Planning D: Society and Space, 29, 649-671.

Mitchell, R. E. and Eagles, P. F. J. 2001. An integrative approach to tourism: Lessons from the Andes of Peru. Journal of Sustainable Tourism, 9(1), 4-28.

Mostafanezhad, M. 2013. The Geography of Compassion in Volunteer Tourism. Tourism Geographies, 15(2), 318-337.

Mostafanezhad, M. 2014. Volunteer Tourism: Popular Humanitarianism In Neoliberal Times, Aldershot: Ashgate.

Mostafanezhad, M. and Hannam, K. 2014. Moral Encounters with Tourism. Aldershot: Ashgate.

Oswin, N. and Yeoh, B. S. 2010. Introduction: Mobile City Singapore. Mobilities, 5, 167-175.

Pacheco, K. 2007. Incas, Indios y Fiestas: Reivindicaciones y Representaciones en la Configuración de la Identidad Cusqueña. Lima, Dirección Regional de Cultura del Cusco, Instituto Nacional de Cultura.

Parker, C. 2009. Tunnel-bypasses and minarets of capitalism: Amman as neoliberal assemblage. Political Geography, 28, 110-120. 
Peruthisweek.com, 2016. http://www.peruthisweek.com/news-tourists-naked-photosmachu-picchu-108985

Popke, J. 2010. Ethical Spaces of Being In-Common. In S. Smith, R. Pain, S. Marston, and J. Jones (Eds.), The Sage Handbook of Social Geographies. London: Sage.

Raymond, E. M. and Hall, C. M. 2008. The Development of Cross-Cultural (Mis)Understanding Through Volunteer Tourism, Journal of Sustainable Tourism, 16(5), 530-543.

Saldaña, J. 2009. The Coding Manual for Qualitative Researchers. London: Sage. Scarles, C. 2012. The Photographed Other: Interplays of Agency in Tourist Photography in Cusco, Peru. Annals of Tourism Research, 39(2), 928-950.

Sin, H. L. 2010. Who Are We Responsible To? Locals' Tales of Volunteer Tourism. Geoforum, 41, 983-992.

Sinervo, A. 2015. Brokering aid through tourism: the contradictory roles of volunteer coordinators in Cusco, Peru. Tourist Studies, 15 (2), 156-174.

Steel, G. 2012. Local Encounters with Globetrotters: Tourism's potential for street vendors in Cusco, Peru. Annals of Tourism Research, 39(2), 601-619.

Tomazos, K. and Butler, R. 2009. Volunteer Tourism: The New Ecotourism?, Anatolia, 20(1), 196-211.

UNESCO, 2015. City of Cuzco. Available online: http://whc.unesco.org/en/list/273

van den Berghe, P. and Ochoa, J. F. 2000. Tourism and nativistic ideology in Cuzco, Peru. Annals of Tourism Research, 27(1), 7-26.

Vrasti, W. and Montsion, J. M. 2014. No Good Deed Goes Unrewarded: The Values/Virtues of Transnational Volunteerism in Neoliberal Capital. Global Society, 28(3), 336-355. 
Waitt, G. and Cook, L. 2007. Leaving Nothing But Ripples On The Water:

Performing Ecotourism Natures. Social \& Cultural Geography, 8, 535-550.

World Bank, 2013. International Bank For Reconstruction and Development, Project Appraisal Document On Aproposed Loan in the Amount of US\$35 Million to the Republic of Peru for the Cusco Regional Development Project. Available online: http://documents.worldbank.org/curated/en/2013/10/18484297/perucusco-regional-development-project

Ypeij, A. 2012. The Intersection of Gender and Ethnic Identities in the Cuzco-Machu Picchu Tourism Industry: Sácamefotos, Tour Guides, and Women Weavers Latin American Perspectives, 39(6), 17-35.

\footnotetext{
' PRONAA stands for Programa Nacional De Asistencia Alimentar; PANFAR stands for Programa De Alimentaciòn y nutriciòn; FONCONDES stands for Fondo De Cooperaciòn para el Desarrollo and MIMDES stands for Ministerio De La Mujer y Poblaciones Vulnerables.
} 


1
2
3
4
5
6
7
8
9
10
11
12
13
14
15
16
17
18
19
20
21
22
23
24
25
26
27
28
29
30
31
32
33
34
35
36
37
38
39
40
41
42
43
44
45
46
47
48
49
50
51
52
53
54
55
56
57
59
60

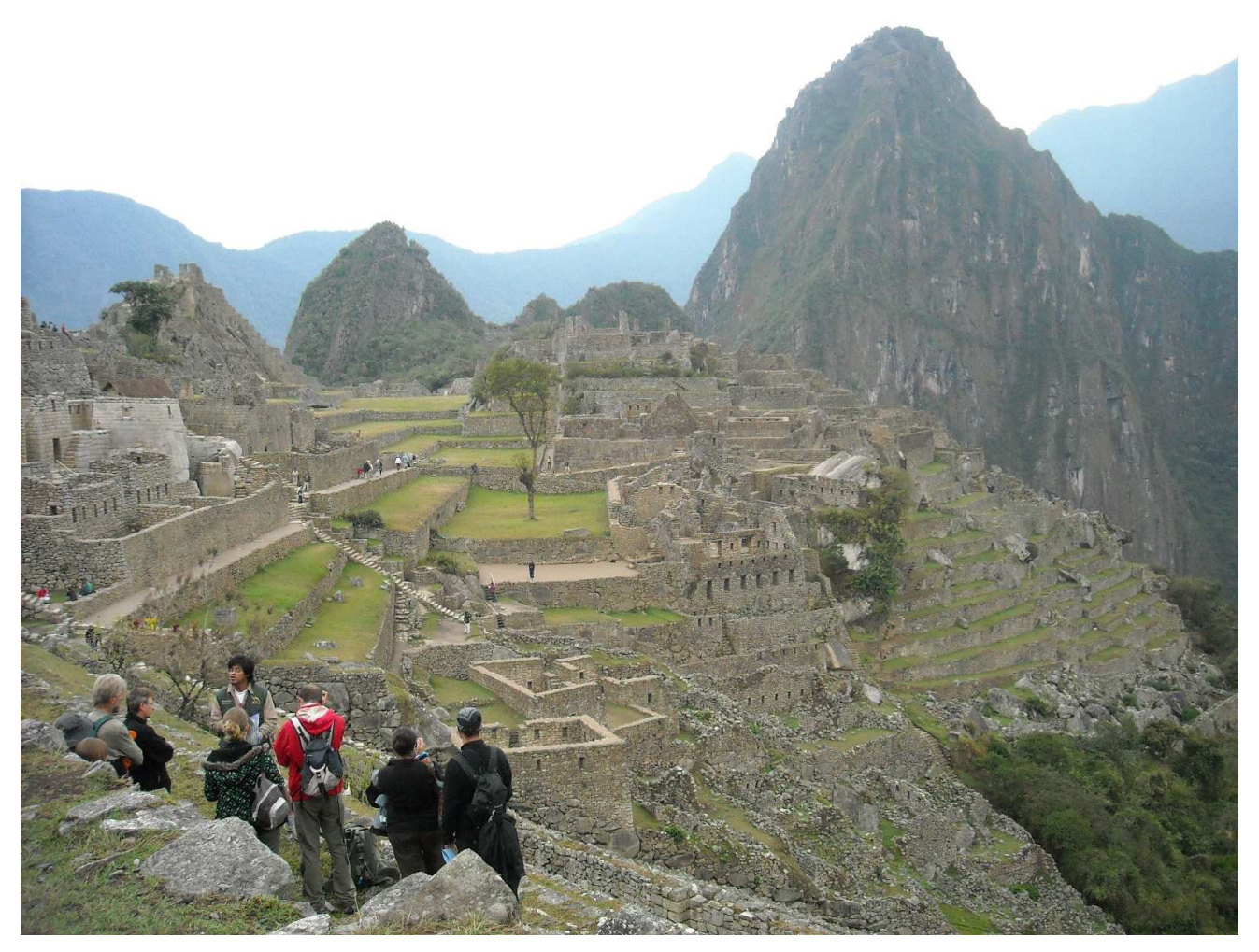

Machu Picchu

$276 \times 207 \mathrm{~mm}$ (300 x 300 DPI) 


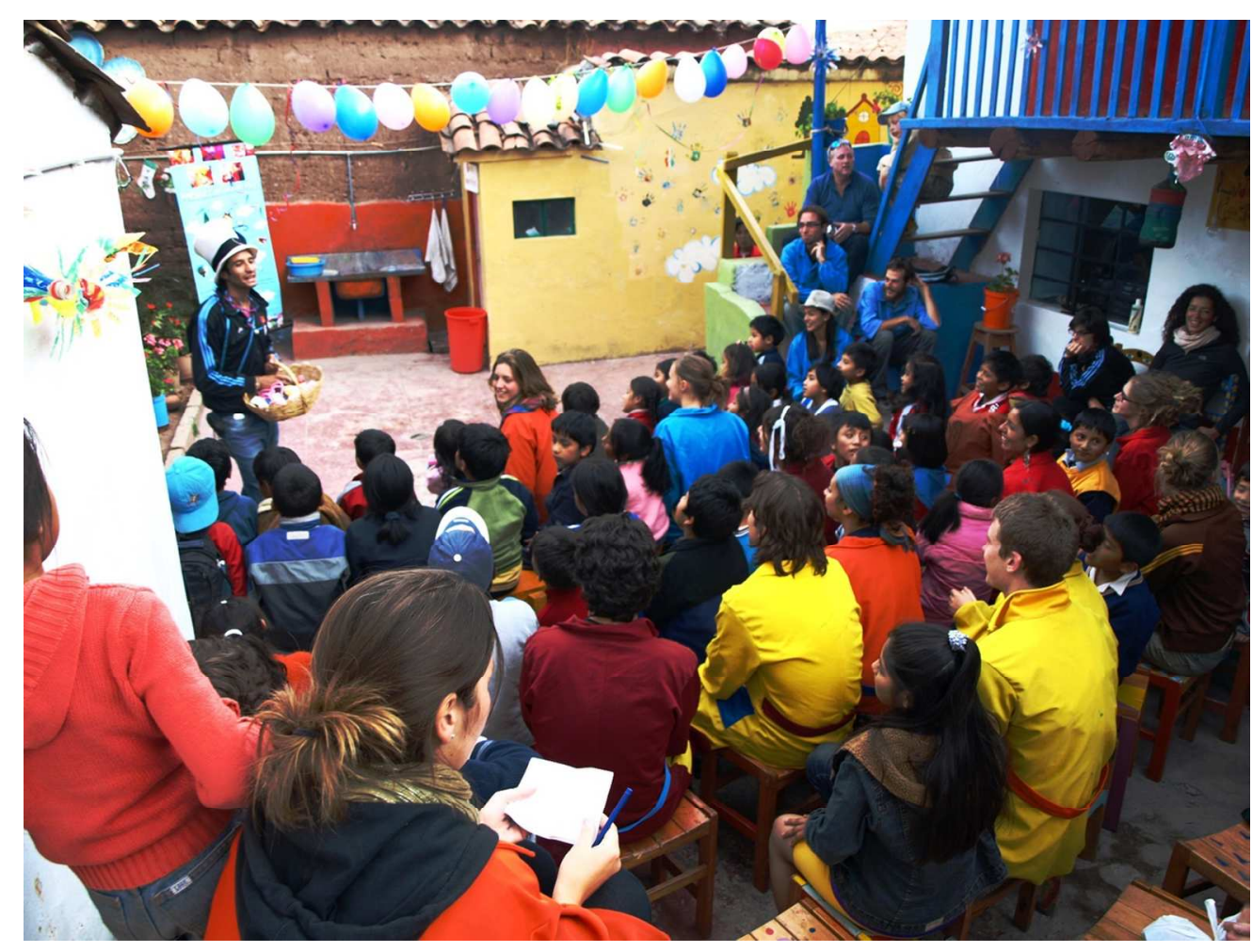

Volunteer Tourism in Cusco $110 \times 82 \mathrm{~mm}(300 \times 300 \mathrm{DPI})$ 
Moral Assemblages of Volunteer Tourism Development in Cusco, Peru

Responses to referee's comments 


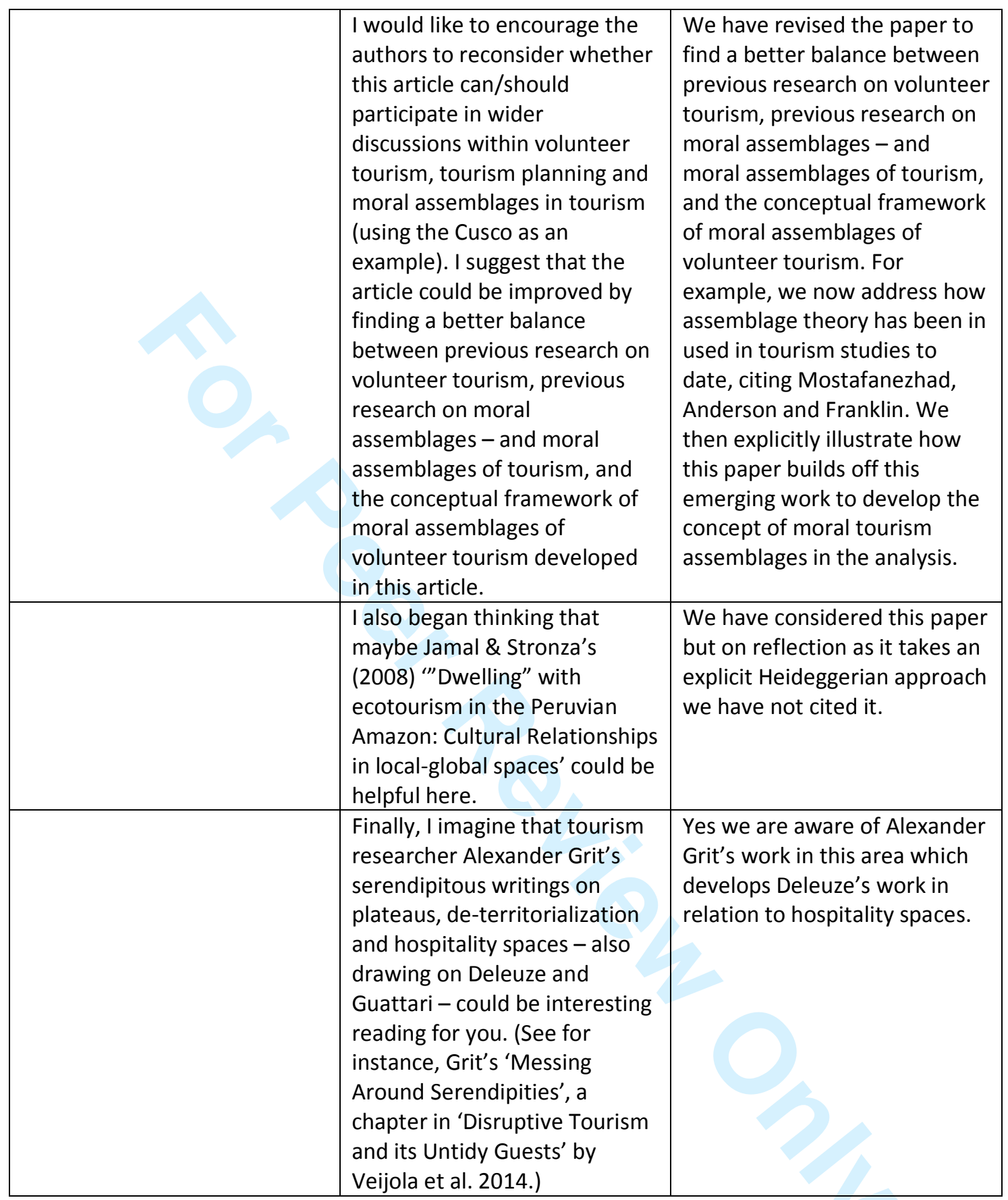

